\title{
CHANGE IN HEIGHT OF THE INDIVIDUAL AMONG THE SELECTED
} ETHNIC GROUPS

\author{
Iju Shrestha *, Hari Sharan Makaju.
}

Department of Anatomy, Kathmandu Medical College and Teaching Hospital, Duwakot, Bhaktapur, Nepal.

\section{ABSTRACT}

Background: People belonging to different ethnic groups seem to have differences in their height. The variation of is known to be determined by genetic as well environmental factors. However very less has been studied about the relation between the height and ethnicity of the individual. The proposed study dealt with finding out the relation between height and ethnicity of the individual.

Objectives: The aim was to assess the relation between height and ethnicity of the individual and also to see if there is any environmental influence on the particular ethnicity

Materials and Methods: The method followed was a cross sectional study conducted in the medical students studying in Kathmandu Medical College and Teaching Hospital (KMCTH), Duwakot, Bhaktapur, Nepal. Height was measured by a stadiometer and ethinicity was recorded as stated by the respondents.

Result: The ethnic groups in our study included the religious groups. Majority of subjects of participation were found to be Hindus (93.86\%). The Hindu ethnic group was seen to be taller with a height range of minimum and maximum of $144.1 \mathrm{~cm}$ and $187.1 \mathrm{~cm}$ respectively. Among the subgroups, the highest mean height was observed to be of the Madhesi $(168.75 \mathrm{~cm}$ ) followed by the Chhetris; the Newars and the Marwadis were seen to be with minimal height among the ethnic categories.

Conclusion: Taller body height in this study was seen in the people in plain region where they are exposed to greater oxygen saturation level and the warmer climate. Hence, the diversity of the geographical topography can be taken into consideration for its environmental factors which can have beneficial influence on the the height of the ethnic group/individual so that they can attain the maximum possible height.

KEY WORDS: Environmental factors, Ethnicity, Genetic factors, Height

Address for Correspondence: Dr. Iju Shrestha, Department of Anatomy, Kathmandu Medical College and Teaching Hospital, Duwakot, Bhaktapur, Nepal. E-Mail: drijushrestha@gmail.com

Access this Article online

Quick Response code

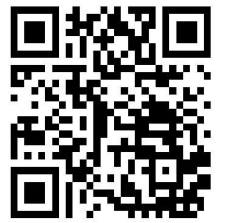

DOI: $10.16965 /$ ijar.2017.537

Journal Information

International Journal of Anatomy and Research

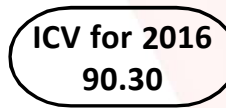
ISSN (E) 2321-4287 | ISSN (P) 2321-8967 https://www.ijmhr.org/ijar.htm DOI-Prefix: https://dx.doi.org/10.16965/ijar

\section{Article Information}

Received: 28 Dec 2017

Peer Review: 28 Dec 2017

Revised: None
Accepted: 02 Feb 2018

Published (O): 05 Mar 2018

Published (P): 05 Mar 2018

\section{INTRODUCTION}

Human height has been a subject of extensive research in the fields of science. Being easy for measurement, relative stability in adulthood and normal distribution in groups of people, it has been a classic anthropometric quantitative trait [1]. Body height among adults is determined by genetic factors and environmental influences during the years of growth [2-4] genetic and environmental factors jointly play role in achieving the final body height. Beside the genetic factors, a multitude of environmental factors can affect height which can act upon during the whole growth period, however, infancy is probably the most sensitive phase regarding external influences $[5,6]$. The role of childhood environment is seen in the increase in body height during the 20th century simultaneously 
with the increase in the standard of living. The most important non-genetic factors affecting growth and adult body height are nutrition and diseases. Short stature is associated with poorer education and lower social position in adulthood. This is mainly due to family background, but other environmental factors in childhood also contribute to this association [7]. Environmental factors affecting growth include nutrition, disease, socioeconomic status, urbanization, physical activity, climate, and psychosocial deprivation [8]. In the presence of adverse environmental conditions, the physical growth of children can decline and even adult height be affected $[6,9,10]$. These and other proximate biological determinants are further associated with social and economic conditions manifesting as socio-economic differences in height both within and between populations [6].

Hence the study will be conducted to see if there is change in height of the individual with respect to the ethnicity and also if there is a correlation between the height and ethnicity of the individual.

\section{MATERIALS AND METHODS}

163 students of studying in Kathmandu Medical College and Teaching Hospital were taken as the subjects for this study. Ethical clearance from IRC, KMCTH was obtained prior to starting the study. Informed consent of participants was taken and socio-demographic indices like age, sex and height were noted.

Ethnicity was recorded as stated by the respondents. The ethnic groups were determined as per the religious group as this group was large and homogeneous despite its diversity. The religious groups were divided into four ethnic groups: Hindu, Buddhist, Muslim and Christian. The Hindus, as they constituted major group, were further subdivided into Brahmin, Chhetri, Newar, Marwadi, Madhesi and Others. Height of the individual was measured in standing erect anatomical position in centimeters through stadiometer. As the study was related to the height of the subjects, those having history of any disease of foot, deformity, fracture, amputation or record of any surgical procedures were not included in this study. Also the subjects who did not give consent were not included in the study.

The data obtained was computed and analyzed using SPSS (Statistical Package for Social Sciences) computer to tabulate the results.

\section{RESULTS}

The ethnic groups in our study included the religious groups of Hindus, Buddhists, Christians and Muslims. Majority of subjects of participation were found to be Hindus (93.86\%) and rest were Buddhists. No Christian or Muslim participation was observed in the study. The minimum and maximum heights observed in the Hindus were $144.1 \mathrm{~cm}$ and $187.1 \mathrm{~cm}$ respectively and those in the Buddhists were $151 \mathrm{~cm}$ and 170.1 $\mathrm{cm}$ respectively. The mean height was observed to be more in the Hindus as depicted in figure 1.

Fig. 1: Variation in mean height in different religious ethnic groups.

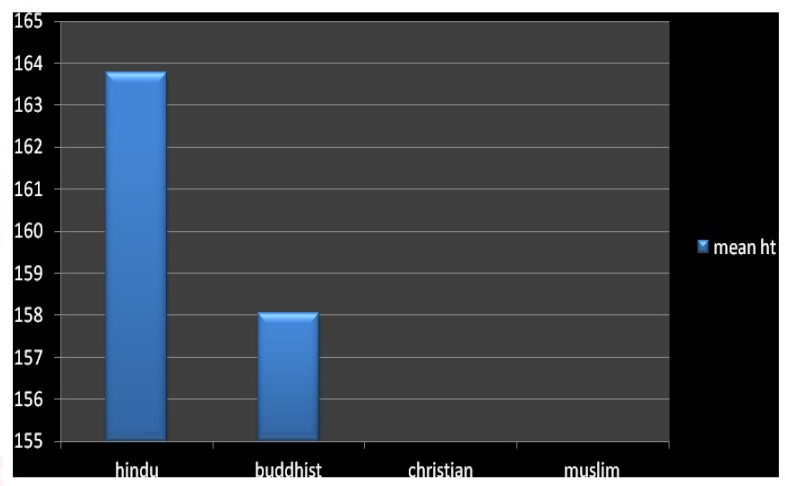

Fig. 2: Variation in mean height in different ethnic groups.

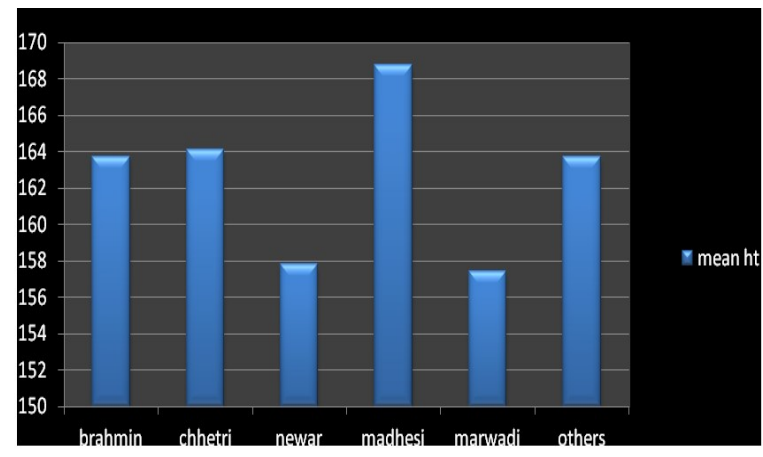

Table 1: Variation in height in different ethnic groups.

\begin{tabular}{|c|c|c|c|}
\hline Ethnicity & $\begin{array}{c}\text { Minimum } \\
\text { Height }(\mathrm{cm})\end{array}$ & $\begin{array}{c}\text { Maximum } \\
\text { Height }(\mathrm{cm})\end{array}$ & $\begin{array}{c}\text { Mean Height } \\
(\mathrm{cm})\end{array}$ \\
\hline Brahmin & 148.8 & 187.1 & 163.7318 \\
\hline Chhetri & 144.1 & 184 & 164.122 \\
\hline Newar & 151.6 & 163.4 & 157.81 \\
\hline Madhesi & 161.2 & 180.1 & 168.7462 \\
\hline Marwadi & 148 & 168.5 & 157.4 \\
\hline Others & 144.9 & 179 & 163.7 \\
\hline
\end{tabular}


As majority of the participants (93.86\%) were observed to be Hindus, this group was further subdivided into : Brahmin, Chhetri, Newar, Madhesi and Marwadi. Representation from the minority groups Dalit, Tharu, Magar was grouped in "Others". Table 1 shows the differences in height in different ethnic groups along with the variation in their mean height.

\section{DISCUSSION}

Body height is a good indicator of childhood living conditions, not only in developing countries but also in modern Western societies. In modern Western societies, about $20 \%$ of variation in body height is due to environmental variation.[7] Nutrition and especially lack of dietary protein is universally the most important environmental factor influencing height, but also childhood diseases, in particular infections, can affect growth [5].

Malnutrition results in failure to grow, involving both weight and height. When malnutrition is corrected, the affected children soon recover, and when this reversal occurs at a young age, most children will attain a complete remission in height and weight to equal their siblings before puberty $[11,12]$.

In our study the highest mean height was observed to be of the Madhesis with $168.75 \mathrm{~cm}$. Madhesis are the people who have lived in the Terai (southern plain ) region of Nepal for generations.[13] The Chhetris were seen to be the second tallest followed by the Brahmins and the others catergory. Whereas the Newars and the Marwadis were seen to be with minimal height among the ethnic categories.

In a study done by Henriette $A$ et al[8], it is mentioned that the season and climate also affects the height of a person. Growth of a person including weight and height occurs rapidly during the spring.[14] Climate is also affected by high altitude, where people exposed to a lower oxygen saturation in the air have a shorter stature [9].

This fact can be attributable to the taller madhesis in our study who live in the southern part of the country where they are exposed to higher oxygen saturation as well as warmer climate. Whereas the the indigenous inhabitants of the Kathmandu valley, the newars are comparatively with a shorter stature reflecting the higher altitude than the terai region. The chhetris and the brahmins are the dominant groups dispersed throughout the country[13] hence showing almost the average height amongst the ethnic groups. The "others" group in our study also showed up almost average height in which the minority ethnic group "tharus" are included; which in turn turned out to be the plain dwellers.

It is also thought that urbanization results in a taller stature[15] owing probably to sufficient food supply, adequate health and sanitation services, education, recreation, and welfare. Though this could not be compared to the findings of our study as it is limited to an institution of a city of a developing country. However Developing countries have also seen to have taller stature and greater weight attained by children from the higher socioeconomic classes [9].

Variations in height of different ethnic groups can be seen as in this study as different ethnic population has different genetic background and live in different environments. It is possible that people from the same ethnic group share similar genetic factors and being in same type of environment can have similar maximum possible heights. However, height heritability can vary from one population to another, or from men to women or even in any two individuals with the same ethnicity. When a given environment maximizes the genetic potential of a population for a given trait, this population tends to have a higher heritability for that trait, and vice versa. Differences in mean standing height found for various ethnic groups[16] may thus reflect socioeconomic and demographic inequalities among ethnic groups $[17,18]$ rather than the effect of genetic variance.

\section{CONCLUSION}

Differences of height can be observed in different ethnic populations. The final height of an individual depends on genetic factors and environmental factors. However, it is to be remembered that the genetic factors determine the maximum possible height whereas it is the environment that determines the individual to reach that maximum possible height. The fooding habit of a particular individual/commu- 
nity, disease, season and climate and also socioeconomic status influence the height.

In a place like Nepal, her great biodiversity and geographical topography can be taken into consideration so as to mark the influential factors upon the height of the ethnic group/individual so that the factors can be utilized in maximizing the genetic potential of a population for a given trait and hence attaining the maximum possible height.

\section{ACKNOWLEDGEMENTS}

All the participants without whom the study would not have been possible

\section{Conflicts of Interests: None}

\section{REFERENCES}

[1]. Jelenkovic A. et al. Genetic and environmental influences on height from infancy to early adulthood: An individual-based pooled analysis of 45 twin cohorts. Sci. Rep. 2016;6:28496; doi: 10.1038/ srep28496.

[2]. Taasdale TW, Sorensen TIA, Owen DR. Fall in association of height with intelligence and educational level. BMJ 1989;298:1292-3.

[3]. Nystrom Peck AM, Vagero DH. Adult body height and chilhood socioeconomic group in the Swedish population. J Epidemiol Community Health.1987;41:3337.3

[4]. Walker M, Shaper AG, Wannamethee G. Height and social class in middle-aged British men. J Epidemiol Community Health.1988;42:299-303.

[5]. Bozzoli C., Deaton, A. \& Quintana-Domeque, C. Adult height and childhood disease. Demography 2009; 46:647-669.
[6]. Steckel R. H. Heights and human welfare: Recent developments and new directions. Explorations in Economic History 2009; 46;1-23.

[7]. Silventoinen K. Determinants of variation in adult body height.Journal of Biosocial Science.April 2003;35(2):263-85.

[8]. Henriette A. Delemarre-van de Waal Environmental Factors Influencing Growth and Pubertal Development by; Environmental Health Perspectives.1993;101 (Suppl 2):39-44.

[9]. Eveleth P. B., Tanner J. M. Worldwide variation in human growth. Cambridge University Press, Cambridge;1990.

[10]. Bogin B. The growth of humanity. Wiley-Liss,New York; 2001.

[11]. Garrow J. S.,Pike M. C. The long-term prognosis of severe infantile malnutrition. Lancet i: 1967;1-4.

[12]. Hansen J. D. L., Freesemann C, Moodie A. D,Evans, D. E. What does nutritional growth retardation imply? Pediatrics.1971;47:299-313.

[13]. Gellner D N. Caste, Ethnicity and Inequality in Nepal. Economic and Political Weekly May 19, 2007;182328.

[14]. Marshall W. A. Evaluation of growth rate in height over periods of less than one year. Arch. Dis. Child. 1971;46:414-20.

[15]. Tanner, J. M., Eveleth P. B. Urbanisation and growth. In: Man in Urban Environments (G. A. Harrison and J. B. Gibson, Eds.), Clarendon Press, Oxford; 1976:144-66.

[16]. Spurgeon JH, Meredith HV, Onuoha GBI. Comparisons of body size and form among ethnic groups of United States college men. Growth. 1986;50:250-8.

[17]. Ling SYK, King NM. Secular trends in stature and weight in southern Chinese children in Hong Kong. Ann Hum Biol. 1987;14:187-90.

[18]. Whincup PH, Cook DG, Shaper AG. Social class and height. BMJ. 1988;297:980-1.

How to cite this article:

Iju Shrestha, Hari Sharan Makaju. CHANGE IN HEIGHT OF THE INDIVIDUAL AMONG THE SELECTED ETHNIC GROUPS. Int J Anat Res 2018;6(1.3):5007-5010. DOI: 10.16965/ijar.2017.537 